\title{
Musikalske praksiser i sosiale mellomrom
}

Refleksjoner omkring relasjonelle aspekter i kunst, estetikk og populærmusikk

Paal Fagerheim

\section{Keywords}

Musicology, ethnomusicology, art theory

\begin{abstract}
This article examines the concept of relational aesthetics, starting with Nicolas Bourriaud's discussion related to art theory. It discusses the concept in relation to music as experiencebased action, where familiar issues between high and low and between art and popular culture are affected. The article emphasizes the "music" as an active social space, characterized by ritualized practices that are active in human life, ways of being-in-the world, and alternative and experimental reality categories.
\end{abstract}

\section{Innledning}

Den franske kunstkritikeren og kuratoren Nicolas Bourriaud (f. 1965) skriver i boken Relasjonell estetikk (1998 [2007]) om det han trekker frem som karakteristisk for sentrale deler av 1990-årenes kunstestetikk, og hvordan denne estetikken fortoner seg som forskjellig fra tidligere modernistiske strømninger i kunstverdenen. I denne artikkelen skal jeg se nærmere på Bourriauds bruk av begrepet relasjonell estetikk, samtidig som begrepet også vurderes i sammenhenger med musikalske praksiser. Dette diskuteres spesielt i forhold til populærmusikalske praksiser som ritualiserte fenomener. I tillegg vil jeg avslutningsvis problematisere maktforhold som strategisk opprettholdes i et større felt av kulturproduksjon. Et sentralt moment blir hvordan tilhengere av "kunsten" søker å distingvere seg selv og sine utvalgte estetiske praksiser gjennom ulike strategier der opprettholdelsen av verdi-dikotomier, forestilte ontologier og sentriske diskurser i høyeste grad må anses som aktive, levende og betydningsfulle i feltet.

Relasjonell estetikk er et begrep basert på både avvisningen av kunstverket som objekt og forestillinger om dets selvrefererende og autonome væren. Den relasjonelle estetikken knyttes av Bourriaud til "estetisk teori som består i å bedømme kunstverkene i funksjon av de mellommenneskelige relasjonene de forestiller, produserer og fremkaller" (Bourriaud 2007:165). Det er dermed en erfaringstradisjon Bourriaud ser den relasjonelle estetikken i 
sammenheng med, ikke en kunsthistorisk tradisjon der estetikken er knyttet til kunstobjekter, autonome og selvrefererende verker. Det erfaringsmessige paradigmet i estetikken vektlegger i stedet det relasjonelle, opplevde og erfarte som kunsten skaper og utløser i en sosial og kulturell kontekst. Han sier om relasjonell kunst at det er "kunstneriske praksiser som tar mellommenneskelige relasjoner og deres sosiale kontekst som teoretisk og praktisk utgangspunkt, heller enn et autonomt og privat rom" (Bourriaud 2007:165). Vesentlig for dette er at estetikkens verdier, meninger og betydninger er situasjonelle, det vil si at de er avhengige av, eller står i en nødvendig tilknytning til, en spesifikk utfoldelse i tid og sted der “publikum” er nødvendige aktører i estetikkens erfaringsbaserte virkninger.

Før jeg betrakter Bourriauds begrep nærmere, er det nødvendig å kort berøre en del generelle problemstillinger knyttet til kunst, musikk og "relasjonalitet”. All kunst innehar og eksisterer på sett og vis i en relasjonell dimensjon, i ulike modaliteter, i og med at kunst som en menneskelig aktivitet utfolder seg for mennesker i en historisk og sosial kontekst. Både skapelsen og opplevelsen av et kunstverk fordrer en aktivisering av menneskelige ressurser, der denne aktiviseringen, samt etterfølgende erfaringsmessige opplevelser, står i relasjonelle forhold til kunstverket, blant annet gjennom dialog. Selv et maleri som objekt har ingen kunstnerisk egeneksistens; det er avhengig av en betrakter som erfarer og opplever noe i forhold til objektet på veggen $i$ en sosial og kulturell sammenheng. ${ }^{1}$

Etnomusikologien og musikkantropologien har lenge vist oss at musikk, eller musisering, som praksis, aktivitet eller "kunst" er uløselig knyttet til sosial organisasjon og kulturelle kontekster. All musikk har også relasjonelle kvaliteter hvis man følger denne tankerekken. Kanskje dette er noe "banalt" å trekke frem? Vel, innenfor den vestlige kunstmusikktradisjonen og modernismen har musikk som fenomen blitt tilskrevet klare kvaliteter i form av kunst som objekt der verket, partituret, står som hovedbærer av meninger, verdier og betydninger $i$ seg selv. Men musikk utøves eller spilles som et auditivt fenomen og oppleves alltid $\mathrm{i}$ en spesifikk kontekst, alltid med ulike konnotasjoner og erfaringskonsekvenser. All musikk krever også dermed en form for medvirkning fra levende individer for å eksistere (spillende, komponerende, lyttende, dansende m.m.), og som individ er man alltid relatert til en form for kollektiv eksistens. Dermed kan man si at musikk eksistensielt sett er relasjonell; mellom dens sosiale praktiserte utfoldelse og dens individuelle

\footnotetext{
${ }^{1}$ Dewey (1934) betoner den levde erfaringen som vesentlig i all estetisk opplevelse, der erfaringen inkluderer interaksjon i form av deltakelse, kommunikasjon og naturlige livsprosesser. "The works and the responses they evoke are continuous with the very processes of living [...] (s. 28).
} 
og/eller kollektive lyttere. Det finnes i dag utallige måter å oppleve og erfare det musikalske på, gjennom konsert, lytting i hodetelefoner, i små grupper, musikk i kjøpesenter, radio, tv og et mangfold andre kontekster og sammenhenger. Likeså er det derfor vanskelig å snakke om kun en relasjonell musikalsk karakter som preger all verdens musikk og dens eksistens: musisering. I tillegg varierer det relasjonelle aspektet stort mellom hvilken sjanger musikk det er snakk om, og også hvilket kulturområde musiseringen befinner seg i. Men for Bourriaud innebærer en relasjonell estetikk noe mer enn dette; noe mer omfattende og barende enn betrakterens, eller lytterens, oppmerksomhet og fortolkning. Vi skal redegjøre for dette nedenfor. Først noen metodiske stikkord.

Jeg vil i denne sammenhengen benytte meg av en del musikalske eksempler, hovedsakelig fra mitt feltarbeid, som er gjort sammen med musikere fra det norske hiphopmiljøet. Feltarbeidet har blitt gjort sammen med ulike utøvere på to forskjellige arenaer, studioarbeid og konserter. I stedet for å studere innspilte musikkstykker, enten på CD, mp3 eller vinyl, har mitt hovedfokus i arbeidet vært den utøvde musikken i sosiale sammenhenger, knyttet til spesifikke kontekster. En viktig forforståelse for dette feltarbeidet har også vært at musikken i slike situasjoner er en aktivitet som skaper rom, er territoriell, preget av mellommenneskelig samhandling og aktiverer sentrale meninger og verdier utover en forestilt egen klangmessig eksistens. Jeg presiserer dermed at musikalske meninger og verdier er knyttet til kontekstuelle faktorer og det sosialt relasjonelle, noe jeg vil vende tilbake til senere. La oss først se nærmere på hva begrepet relasjonell estetikk innebærer, og samtidig plassere det i en historisk kontekstuell ramme.

\section{Relasjonell estetikk}

Bourriaud er særskilt opptatt av hva som karakteriserer deler av samtidskunsten og spesielt de retninger innenfor kunstverdenen vi har fra 1990-årene, retninger som gradvis visker ut grensene mellom skulptur, konseptkunst, installasjon, performance, utstilling og liknende. Bourriaud eksemplifiserer sin argumentasjon med en beskrivelse av kunstverk fra kunstnere som Rirkrit Tiravanija, Philippe Parreno, Vanessa Beecroft og Carsten Höller. Disse kunstnerne og deres uttrykk står ifølge Bourriaud for de mest aktive og aktuelle aktivitetene på 1990-årenes kunstarena, aktiviteter som baserer seg på interaktivitet, det sosiale og det relasjonelle. Utviklingen av disse kunstformene ser Bourriaud i sammenheng med kapitalismen i den vestlige delen av verden og dens fremmedgjøring av subjektet og "ekte" sosiale relasjoner i dagens samfunn; relasjonell kunst fremstår i denne historiske konteksten som “utopier om nærhet” (Bourriaud 2007:11). Den kontekst Bourriaud arbeider med, er 
relatert til modernismen på flere måter. Modernismen i kunsten, avantgarden, futuristene, tilhørende tiden fra ca. 1920, var preget av blant annet motstand, avvisning, eksperimentering og klare ansatser (gjerne politiske) om hva som vil og bør komme av samfunnsmessige utviklinger. Den relasjonelle kunsten derimot, i vår postmoderne tidsalder, "modellerer mulige universer" heller enn å forutsi, forbedre eller reagere mot. Det relasjonelle formspråket er dermed ikke et "lineært brudd" som handler om fortiden eller fremtiden, det kan betraktes som et brudd $i$ nåtid og for nåtiden der alternative eksistensielle potensialer for livsutfoldelse, opplevelse og virkelighetsfortolkning her og $n a ̊$, parallelt med forestillingen om en "primær virkelighet", er sentrale størrelser. Samtidskunsten er heller ikke produsert ut fra ideen om en låst, autonom estetikk der kunstverkets mening og verdi ligger i dets (forestilte) selvrefererende eksistens. Bourriaud sier at " [...] man kan ikke lenger betrakte samtidskunsten som et område å beskue [...]. Samtidens kunstverk gir seg i stedet som en varighet å gjennomleve, som en åpning mot grenseløs meningsutveksling” (Bourriaud 2007:18). Det temporære, opplevd som en del av kunstverket, gjennom kunstverket, eller med kunstverket, er dermed med på å skape, og er en forutsetning for, den relasjonelle estetikken. "Kunsten" blir dermed ikke lenger det som henger på veggen eller stilles ut i monteren.

I tillegg til den industrielle kapitalismen og brudd med modernismen, er det ifølge Bourriaud utviklingen av den urbane bykultur i Vesten som har bidratt til disse retningene $\mathrm{i}$ kunstverdenen. Denne formen for lokal organisasjon, Gesellschaft, gjennom store urbane sentre, har "muliggjort opplevelsen av nærhet og gjort den vanlig: Byen er det håndfaste symbolet og den historiske rammen for samfunnets tilstand" (Bourriaud 2007:18). Bourriaud situerer dermed kunstpraksiser og estetikk historisk og i kontekstuelle rammer. Det er altså økende former for urban sosialisering og intensiveringer av sosiale møter som fører til større intersubjektivitet som “essens” i kunstpraksiser. Temaer som "det å være sammen” og møter mellom kunst og betrakter blir sentrale størrelser i den kollektive meningsproduksjonen. Bourriaud snakker her om et urbant nærhetssamfunn der kunsten er spesielt egnet som uttrykk, nettopp fordi den "innsnevrer" relasjonsrommet og skaper andre "rom". Kunsten er altså for Bourriaud et “åsted for en spesifikk sosial produksjon” (Bourriaud 2007:20), noe som henger sammen med at kunstverket representerer et sosialt (mellom)rom (interstice). Dette begrepet, lånt fra Karl Marx, ble i sin tid brukt om utvekslingssamfunn som ikke er underlagt den samme kapitalistiske økonomien; de er fritatt fra "loven om profitt" (Bourriaud 2007:20). 
Mellomrommet er et rom av menneskelige relasjoner som, selv om det føyer seg mer eller mindre harmonisk og åpent inn i det globale systemet, foreslår andre muligheter for utveksling enn de som er virksomme i det systemet. Akkurat slik (som et (mellom)rom) er samtidskunstutstillingen innenfor handelen med fremstillinger: Samtidskunsten skaper frie rom, tidsrom der rytmen motsetter seg og er en annen enn den som styrer dagliglivet. Den åpner for en "mellommenneskelig handel" som er forskjellig fra de "kommunikasjonssonene" som påtvinges oss. Den nåværende sosiale konteksten begrenser mulighetene for mellommenneskelige relasjoner, i like stor grad som den oppretter rom nettopp for dette formålet (Bourriaud 2007:20-21).

For Bourriaud er utstillingen det "privilegerte stedet", representasjonen, for denne formen for kommunikasjon og sosial samhandling; det han også kaller “øyeblikks-kollektiver”. En bedømmelse av slike utvekslingsområder bør skje ut fra visse estetiske kriterier: Man bør analysere formens sammenheng og den symbolske verdien " $i$ den "verden" som foreslås, med utgangspunkt i det bilde av menneskelige relasjoner som verket reflekterer" (Bourriaud 2007:22). Kunsten er dens utfoldelse i tid og rom; kunstens eksistens er den samhandling og kollektive erfaring som oppstår der og da i aktiverte samhandlinger mellom individer, kollektiv, objekter og artefakter.

Det relasjonelle perspektivet på estetikk er også opptatt av konseptene varighet og sted, i stedet for å føre en ensidig belysning på det konkrete objektet. Hendelser kan vel så gjerne være kunstneriske ting: “[...] den kunstneriske tingen gir seg noen ganger som "hendelse" eller som en helhet av hendelser som produseres i tid og rom. [...] Rammen utvider seg fra å omfatte ett isolert objekt til å omfavne en hel scene” (Bourriaud 2007:27). Samtidskunstverkets form strekker seg dermed ut over sin materielle form. Formbegrepet er altså også relasjonelt hos Bourriaud, som trekker frem prosess som et viktig element i stedet for stabilitet og formfasthet. Et begrep han i større grad bruker om dette, er formasjoner, noe som hentyder til at det (kunstverket) kun oppnår form gjennom møter og i dynamiske relasjoner mellom kunstverk og andre formasjoner $i$ tid og rom. "Formen" er ikke på forhånd gitt, men utfolder seg først når den settes i gang og aktiviseres i menneskelig samhandling. Formen oppstår gjennom en dialog opprettet av kunstneren.

Essensen av den [relasjonelle] kunstneriske praksis ligger dermed i opprettelsen av relasjoner mellom subjektene: Hvert enkelt kunstverk blir et forslag til hvordan verden kan bebos sammen, og hver kunstners arbeid blir et utspring for ulike forhold i verden, som igjen genererer nye forhold, og så videre, inn i 
evigheten. [...] Innenfor rammen av en "relasjonistisk" kunstteori representerer intersubjektiviteten ikke bare den sosiale rammen rundt mottakelsen av kunsten [...] men den blir også essensen i den kunstneriske praksis (Bourriaud 2007:29$30)$.

På samme måte kan man si at musikk er et fenomen som er preget av de samme "essensene". Musikk, eller musisering, som vi foretrekker som aktivitetsbetonende begrep, handler i stor grad om å opprette sosiale relasjoner mellom subjekter, om å opprettholde, bekrefte eller feire identifikasjoner til en gruppe mennesker, eller antyder forslag til hvordan individuell kollektiv eksistens kan eller bør utfolde seg i tid og rom. Aktiviteten “å musisere” er en intersubjektiv praksis, en aktivitet som i tillegg til det utøvende også omfatter lytting, komposisjon, dans og bevegelse til musikk. Hvis det finnes "essenser" i musikk (musikalske praksiser), påstår jeg her at de er å finne i relasjonene mellom de utøvende og de deltakende subjektene (det individuelle kollektive) som i en spesifikk situasjon skaper en hendelse, væren-i-verden, et øyeblikk og en måte å "bebo verden” på.

I tillegg til at den relasjonelle estetikken kan sies å være en aktiv enhet i det sosiale spillet mellom musikere og mellom musikere, produsenter og teknikere i studioarbeid, baserer den seg også på en aktiv og intervenerende deltakelse av publikum, dette i form av blant annet en aktiv dialog og et samspill mellom verket og publikum; skillet mellom kunstverk og kunstbetrakter blir mer problematisk å definere, betrakteren blir ikke en bestanddel utenfor verket, men en del av verket. Denne utviklingen mener Bourriaud må ses i sammenheng med den nevnte interaktivitetskulturen som i dag preger samfunnet vårt. Det er mellommenneskelige relasjoner mellom aktive mennesker og den verden som bebos, som preger kunsten.

[...] utover kunstverkenes iboende relasjonelle karakter, har referansene for menneskelige forhold nå blitt kunstneriske "former". Tilfeldige møter, avtaler, demonstrasjoner, ulike typer samarbeid, spill, fester, "samhandlingssteder", kort sagt helheten av måter å treffes og skape relasjoner på, representerer i dag estetiske objekter og kan derfor også studeres som det (Bourriaud 2007:38-39).

I konsertsituasjoner er det, ut fra mine observasjoner, essensielt for musiseringen at samhandling mellom scene og publikum er tydelig til stede, og konsertstedet endres fra et hvilket som helst sted til et samhandlingssted der relasjoner dannes og utfolder seg i det musikalske forløpet. Den aktive deltakelsen fra publikum tar ofte form av for eksempel vokal call and response, gestikulering, rytmisk kroppstilstedeværelse, korte melodiske innspill styrt 
fra scenen, kommunikasjon og blikkontakt med musikere, med mere. Dette er essensielle faktorer i mye musikalsk praksis, så vel som den relasjonelle kunsten Bourriaud henviser til. Men dette krever at vi også anerkjenner den musikalske hendelse som musikkens primære estetiske objekt, ikke kun den musikalske teksten, noe jeg kommer tilbake til nedenfor.

\section{Nærhet og mikroutopier}

Nærhetsstrategier er grunnleggende i dagens sosiale og kunstneriske praksiser, slik som “hverdagslige mikroutopier og etterliknende strategier" (Bourriaud 2007:42). ${ }^{2}$ Dette har også en gyldighet i musikalske kretser, og her kan vi se at Bourriaud berører et viktig tema som eksempelvis omhandler innholdet i mye rapmusikk. Hverdagslige mikroutopier er ofte tema i raptekster; tema om lokalmiljø, gata, damer man ønsker seg, skryting om bil og bling bling, krangel med lensmannen, festen fra i går og ulike sosiale problemstillinger. Også det bredere landskapet innenfor antropologi og kulturstudier vektlegger fra 1990-årene det lokale, det dagligdagse, som også synes å prege kunstverdenen. Etterliknende strategier er også i sentrum av rappens estetiske praksis. Sampling av tidligere innspilt musikalsk materiale er hovedkilden til skapelsen av de lydspor som raptekster fremføres sammen med. Små lydfragmenter kombineres med nye lydelementer som settes sammen i loopbaserte beats. Dette fremføres live, som oftest av en DJ, opprinnelig ved hjelp av to vinylspillere og en mikser. Funk, disko, soul og rhythm and blues spilles fra plater og mikses sammen live til et sammensatt rytmisk lydbilde som også ofte består av ikke-musikalske samples fra eksempelvis radiosendinger, fjernsyn, film, offentlige taler og andre kilder fra offentligheten. Den relasjonelle kunstens estetikk er også strategisk i og med at den tar tak i eksisterende identiteter, merker, "brands", merkevarer og tidligere elementer for fra dette å skape noe nytt. I tillegg til å være preget av intersubjektivitet mht. behovet for deltakelse fra "publikum”, er også den relasjonelle estetikken intertekstuell i og med at den bruker nettopp tidligere materiale og eksisterende elementer, sammensatt i nye kombinasjoner preget av referanser og imitasjon. ${ }^{3}$ Nærhet til et personlig nivå er også å se i det performative som preger rapmusikk. Aktørene baserer i stedet sin praksis på sine egne personligheter og mer autentiske dagligdagse væremåter, egne livshistorier eller selvbiografier. Dette omfatter også aktørens

\footnotetext{
${ }^{2}$ Bourriaud fremhever dette til forskjell fra revolusjonene på 1800-tallet og de store sosiale utopiene fra 1960årene.

${ }^{3}$ Her kan vi også se en parallell til vitenskapelig virksomhet som gjennom 1800- og 1900-tallet har beveget seg fra betoningen av store makromodeller (Marx, Weber, Durkheim og Levi-Strauss) til mer lokalt forankrede og aktørbaserte forståelsesmodeller (eksempelvis Latour (2005) og Appadurai (2006)).
} 
egne spesifikke erfaringer i en kultur eller i verden. Disse gjøres til gjenstand for performativ praksis gjennom bevisstgjøring og aktivisering i tid og sted. Den individuelle, "ekte" og "autentiske" personen brukes i performance. ${ }^{4}$ Det er derfor vanskelig å dra noe skille mellom den "egentlige" personen som utøver en performativ hendelse, og den som opptrer i selve performancen. Det selvbevisste og individorienterte kan sies å prege mennesker i vår vestlige kulturkrets. ${ }^{5}$ I det populærkulturelle feltet kan vi i dag erfare dette spesielt gjennom media, der det dagligdagse, virkelige, nære og autentiske ofte står i fokus. Realityserier, nære personlige portretter, intervjuer og "vanlige" menneskers livsbiografier danner ofte materiale for både fjernsyns- og radioprogram. Rapmusikalsk praksis er således relatert til realitysjangeren gjennom etisk-autentiske koder om å “keepin' it real”. Rap som vokalsjanger ligger nærmere det dagligdagse, virkelige og autentiske hos utøvere enn sang. Individer som er involvert i dagligdags kommunikasjon, benytter seg i stor grad av verbalt språk og gestikulering, momenter rap er nær relatert til. Det sanglige ser vi her som musikalsk teatralsk praksis der en rolle antas gjennom fremføring, mens rap i stedet er lydmessig mer nært individers daglige performative væren, på samme måte som realityserier skiller seg fra såpeopera. Den rolle som fremsettes i live rapping, er i større grad rapperen sin personlige; det performative i rap baserer seg på utøverens egne "autentiske" og virkelighetsnære væren og sosiale posisjon. Rappere "bruker" ofte seg selv og sin dagligdagse identitet uten å tre inn $\mathrm{i}$ noen annen rolle: Det virkelige, i motsetning til det "kunstlige" og konstruerte i rap er et viktig kvalitetskriterium. Det "autentiske" er således en viktig verdi i rap som musikalsk praksis, og aktører betoner det å vare seg selv lik. Selvet poseres i stedet for at en rolle spilles.

Ved å vektlegge samhandlingssteder, rom og tid, utgjør relasjonelle kunstverk relasjonelle "mikroterritorier". De tilbyr opplevelser mediert gjennom "overflateobjekter" eller "umiddelbare opplevelser" (Bourriaud 2007:45), samtidig som kunstpraksisen søker etter å opprette konkrete rom der betrakteren tilbringer tid og opplever. Kunsten er ikke lenger verk eller objekter som henger på veggen eller stilles ut på museum for betraktning. Bourriaud fremhever at selve kunsten blir mer som en tilstand å erfare, en hendelse å oppleve, en territoriell konstellasjon av møter, objekter, erfaringer og uavklarte hendelsesforløp og gjerne

\footnotetext{
${ }^{4}$ Også i navn på låter, eksempler kan være Tungtvanns "Ekte menneske” og “ $Æ$ e”.

${ }^{5}$ Se eksempelvis Larsen (2009), som grundig behandler utviklingen av subjektivitet, personlighet og den autonome individualitet $\mathrm{i}$ den vestlige kulturkrets.
} 
alternative erfaringspotensialer. Mellommenneskelige relaterte erfaringer og opplevelser danner basisen for kunstens intensjon, form og teoretiske bakgrunn:

Det teoretiske og praktiske bakteppet for dette tiårets kunst [1990-årene] er i stor grad sfæren av mellommenneskelige relasjoner. Slik blir utstillinger [...] sosiale modeller som egner seg til produksjon av menneskelige relasjoner, på samme måte som en arkitektur bokstavelig talt "produserer" bevegelsene til de som befinner seg innenfor den (Bourriaud 2007:99-100, mine uthevinger).

I en musikalsk kontekst kan vi se liknende forskjeller i fremføringspraksis. Hvis den musikalske konserten ses på som en sosial modell for menneskelige relasjoner, har vi klare forskjeller mellom den klassiske symfonikonserten og rapkonserten. I musikkestetikkens tradisjon er det ikke naturlig å tenke på musikk som sosial modell og dette som det primære studiefeltet. Det er snarere det fremførte verket, dets melodiske eller harmoniske indre liv, som danner grunnlaget for musikalsk estetikk.

Bourriaud viderefører sin argumentasjon om kunsten som noe som oppstår og eksisterer i tid og rom blant mennesker, som en erfaring, og som er lik sosialt liv. "Kunsten er laget av det samme stoffet som sosiale utvekslinger," sier Bourriaud, og mener at kunsten i tillegg er (relativt) sosialt gjennomsiktig. Med dette mener han at kunstverket sikter utover "sin egen eksistens i rommet” (Bourriaud 2007:57) og er åpent for dialog og diskusjon. Et sentralt aspekt ved kunstverket er dermed at det er forhandlende, og at det må ses på som en midlertidig prosess som utspiller seg lokalt og sosialt til en viss tid. Bourriaud er opptatt av rom og tid nettopp fordi disse enhetene er svært sentrale i den relasjonelle estetikken; kunstverkene utfolder seg sammen med mennesker i løpet av et visst tidsrom og på et spesifikt sted som aktivt brukes av betraktere. Dette minner oss også om musisering, der musikken utfolder seg sosialt og aktivt oppleves (brukes) av tilhørere. Musikk, å musisere, er en intersubjektiv samhandlingserfaring:

Rommet der verkene utfolder seg er helt og holdent et samhandlingsrom, og er frigjørende fra "massemedienes tvangsmessighet". [...] De kan sies å produsere steder der alternative sosiale former, kritiske modeller eller konstruerte øyeblikk av samvær kan utvikles. [...] Kunstverket gir seg i dag som et sosialt (mellom)rom hvor disse opplevelsene, disse nye "livsmulighetene", blir mulige. Det synes viktigere å finne mulige relasjoner med sine naboer enn å få “morgendagen til å synge". Det er alt, men det er enormt (Bourriaud 2007:62$63)$. 
Hva er det da egentlig som foregår i den relasjonelle kunsten som vi i tillegg kan sammenlikne med utøvelsen av musikk? La oss oppsummere noen momenter vi til nå har berørt. For det første etablerer den relasjonelle estetikken det Bourriaud kaller “øyeblikksfellesskaper”, sosiale (mellom)rom der sameksistens og mellommenneskelige relasjoner står sentralt som estetiske premisser. Slike møter mellom mennesker er potensielt intensive og ladede territorier der ens personlighet, identifikasjon, det kollektive og ens erfarte tilstedeværelse blir "forsterket". Dette kan nok også være relatert til en verdi i dagens vestlige kultur, en verdi som står imot tanken om "tradisjonell” frigjøring og hyperindividualitet: "I våre postindustrielle samfunn er det ikke lenger individets frigjøring som er mest prekært, men frigjøringen av mellommenneskelig kommunikasjon, frigjøringen av eksistensens relasjonelle dimensjon." Det er dermed i det relasjonelle kunstverket (og i mange musikalske praksiser) en viktig "feedback-sone", en sone som vektlegger "samarbeid, fest, kollektiv og deltakelse; prosjekter som utforsker de mange mulige relasjonene til den Andre" (Bourriaud 2007:86).

\section{Mellom relasjonell estetikk og populærmusikalsk ritualisert praksis}

I drøftingen om musisering og dens relasjonelle kvaliteter bør vi også se nærmere på de konsepter musikkforskeren Christopher Small utvikler i bøkene Music of the Common Tounge (1987) og Musicking (1998). Ifølge Small er ikke musikk en ting eller et objekt, men en menneskelig aktivitet: "Music is not primarily a thing or a collection of things, but an activity in which we engage" (Small 1987:50). Han utvikler begrepet "musicking", endrer ordet "musikk" til et verb som på norsk kan overføres til det 'å musisere’. Begrepet musisering (musicking) innehar også konnotasjoner til praktisk aktivitet der vi som relasjonelle aktører (lyttere/publikum/tilhørere) står i et aktivt forhold til den utøvde musikken. Ordet musisering defineres dermed ikke bare gjennom konseptene "fremføring" og "komposisjon", men også gjennom lytting og dansing til musikk, samt det intervenerende i den musikalske territorielle hendelsen $i$ tid. Det vi bør legge spesielt merke til her, er at Small vektlegger musikk som en "kunstform" in which we engage. Det er en aktivitet som har klare relasjonelle kvaliteter der meningsaspekter ligger i mellommenneskelige erfaringer. "Musikk" finnes således ikke for Small. Forestillingen om det autonome objektive musikalske kunstverk er kun en del av en musikalsk rituell konstruksjon og prosess i den vestlige industrielle verden, en konstruksjon som i ritualisert adferd søker å bekrefte og utforske et spesifikt samfunns mytologi og organisasjon. 
Musisering er en aktivitet som ligger i kjernen av mellommenneskelige relasjoner: “[...] musicking is concerned with the exploration, the affirmation and the celebration of relationships" (Small 1987:50). Small bruker vestlig konsertmusikk som et eksempel på en musikktradisjon som utforsker, bekrefter og feirer et spesifikt sett med verdier i den kulturen musikken oppstod. Dette industrielle, kapitalistiske samfunnet som blant annet er preget av en skarp arbeidsdeling, avgrensning mellom aktiviteter, systematikk, hierarki og ikkepersonlighet. Dette ser vi for eksempel i det klassiske symfoniorkestrets aktiviteter. Musikerne er anonyme, publikum sitter stille og lytter, rommet og de fysiske omgivelsene er klart definert for denne aktiviteten, og en dirigent styrer aktiviteten fast gjennom sin posisjon og gestikulering. Aktiviteten er hierarkisk, strukturert, formalisert og institusjonalisert, noe som ifølge Small henger sammen med det industrielle, kapitalistiske samfunnets historie, struktur og karakter. Andre steder beskriver Small ulike sjangere fra den afrikanskamerikanske musikktradisjonen (jazz, rock, rap, blues m.m.) i samme ordelag. "The musicians and their audiences are jointly [...] working to explore, affirm and celebrate their identity; the techniques may often be crude, even rudimentary, but the message they bring is always clear: this is who we are" (Small 1987:392). Small trekker her frem hendelser, det relasjonelle mellom musikere og lyttere, samt det mellommenneskelige som vesentlige bestanddeler i musikalsk kunstnerisk aktivitet, uavhengig av sjanger eller status.

Jeg har tidligere hevdet at aktørers praksis i blant annet studioaktiviteter og konsertsammenhenger bør anses som former for "liminal sosialisering", der "lek, humor, alvor og en ritualisering av alternative meningsunivers og måter å forholde seg til andre aktører og verden på danner grunnlaget for både individuelle og kollektive meningskonstruksjoner" (Fagerheim 2010). Dette kan ses som et motsetningsforhold til dagligdagse, normerte og konvensjonelle væremåter i samfunnet. Regler, plikter, formålstjenlighet, strukturerte og forpliktende momenter i subjekters livsverden settes her midlertidig til side, og andre alternative praksiser betones. Dette er etablerte tanker innenfor antropologien, der konsepter som liminalitet, communitas og alternative sosiale modaliteter betoner viktige sosiale prosesser. Antropologen Victor Turner trekker frem dette som:

[...] two major "models" of human interrelatedness, juxtaposed and alternating. The first is of society as a structured, differentiated, and often hierarchical system of politico-legal-economic positions with many types of evaluation, separating men in terms of "more" or "less". The second, which emerges recognizably in the liminal period, is of society as an unstructured or 
rudimentarily structured and relatively undifferentiated comitatus, community or even communion of equal individuals [...] (Turner 1969:96).

Også sosiologen Simon Frith nevner erfaringen med alternative sosiale relasjoner som en vesentlig meningsdimensjon i populærmusikalsk praksis, i tillegg til soniske kvaliteter og tilknytninger til sjanger, tradisjoner eller repertoar:

Whether we're talking about Finnish dance halls in Sweden, Irish pubs in
London, or Indian films in Trinidad, we're dealing not just with nostalgia for
'traditional sounds', not just with a commitment to 'different' songs, but also
with experience of alternative modes of social interaction (Frith 1996:124).

Her synes det å være en sosial dimensjon som i stor grad utgjør viktige meningsaspekter og betydninger ved musisering, og som er relatert til andre områder for sosial interaksjon. Sosialantropologen Svein-Halvard Jørgensen nevner frikjøreres nettverk innenfor snowboardmiljøer som "fundamentert i aktivitet". Denne aktiviteten "danner grunnlag for handlingsalternativer og virkelighetsforståelser langt utover selve frikjøringen". Frikjøring er generativ i og med at aktiviteten produserer kognitive og kroppslige skjema for handling ut over selve hovedaktiviteten. Den er også rituelt preget i pendlingen "mellom kontroll og kaos" eller som "en rituell handling i en verden hvor kontrollerte omgivelser har stått som ideal for mesteparten av vår aktivitet” (Jørgensen 2004:134-135). På samme måte som aktører innenfor rap dyrker særskilte måter å være på - spesielle samarbeidsformer og musikalsk sosialisering - danner også de grunnlag for en mer helhetlig rekonfigurasjon av virkeligheten som går ut over deres spesifikke praksis knyttet til studioarbeid. Disse aktivitetene gir opplevelser og erfaringer hvis kvaliteter overføres til andre områder i deres hverdag. Musikalsk praksis er dermed en måte å være på, å leve livet på og å utforske alternative meningsunivers på. Etnomusikologen John Miller Chernoff presiserer også dette i sin studie av musikere i Ghana, gjennom dette velbrukte sitatet:

African music is a cultural activity, which reveals a group of people organizing and involving themselves with their own communal relationships - a participant-observer's comment, so to speak, on the processes of living together. The aesthetic point of the exercise is not to reflect a reality, which stands behind it but to ritualize a reality that is within it (John Miller Chernoff 1979:36, originale uthevinger). 
Hvis dette er karakteristisk for afrikanske musikkpraksiser, vil vi kunne si at det også er talende for de populærmusikalske praksiser vi her har sett nærmere på. Ett aspekt som preger nettopp disse praksisene, er performativitet. Det performative som utfolder seg i musikalske praksiser, bør nettopp anses som det primære meningsbærende i en gitt musikalsk praksis. "What is important is not just of musical performance, but good performance, if music and dance are to make a social event 'happen"' (Stokes 1994:3). Stokes betoner her et svært viktig stikkord: "happen". Iboende i denne viktige dimensjonen er troverdighet og anerkjennelse i dialektikken mellom utøver og publikum. Dette er gjensidige elementer av den musikalske hendelsen; elementer som er med på å nedtone distinksjonen mellom lytter og utøver. I praksis kan denne gjerne være markant symbolisert gjennom avstand (eksempelvis scenepublikum, backstageområde-publikumsområde). Men i hvor stor grad den musikalske hendelsen er vellykket, må disse aspektene tas med som grunnleggende premisser.

Musikalsk praksis henger også sterkt sammen med det som den franske sosiologen Pierre Bourdieu kaller symbolsk kapital. Denne er viktig for at musikere skal kunne opptre med en viss mengde anerkjennelse og tyngde. "[...] the weight of different agents depend on their symbolic capital, i.e. on the recognition, institutionalized or not, that they receive from a group" (Bourdieu 1991:72, 111). Denne "mottakelsen" er en vesentlig del av en performance; det er denne kollektive tilstedeværelsen, dialektiske dynamikken og verbale direktheten som på mange måter gjør en hendelse performativ. I rap dyrkes denne svært tydelig og må sies å være et vesentlig, bærende element i rappens praksis.

For å vende tilbake til Bourriaud: Kunst kan også ifølge ham ses på som en oppfinnelse av livsmuligheter, noe som belyser hans relasjonelle (!) ståsted til både Christopher Small og de perspektivene fra antropologien vi her har drøftet. "[...] subjektivitetens endelige målsetting er ikke annet enn et evig forsøk på individualisering. Den kunstneriske praksisen utgjør et egnet territorium for denne individualiseringen, ved å tilby potensielle modeller for menneskelig eksistens generelt" (Bourriaud 2007:127). For det første kan disse perspektivene være nyttige for å tenke nytt om "kunst" som begrep; ikke som objekter, men som praksis. For det andre gir de ansporinger til nye kriterier for å evaluere musikkens status som noe annet enn "kunst", som praksis. For det tredje gir de muligheter for å se på populærmusikalske sjangere ut fra et "kunstteoretisk" ståsted. Men dette er ikke helt uproblematisk, noe vi også får eksempler på i Bourriauds bok. Her nærmer vi oss de gamle problemstillingene omkring høy og lav, samt kunst versus underholdning. 


\title{
Avslutning
}

Denne artikkelen har drøftet en kontaktflate, et berøringspunkt eller et mellomrom, mellom populærmusikalske praksiser og “kunst”. Det relasjonelle synes her å være et felles aspekt. På mange måter kan vi også si at dette er visse politiske prosesser som er aktive i dette problematiske mellomrommet. Maktforhold opprettholdes strategisk i dette feltet, spesielt med tanke på å beskytte kunsten som egeneksistensiell, opphøyd og verdifull (både i form av monetær og symbolsk kapital) (Bourdieu 1984). Dette står naturligvis i sammenheng med den samme gamle sangen vi alle har hørt: om skillet mellom kunst og pop. Distinksjonen mellom høyverdighet (kunst) og lavkultur (populærkultur og underholdning) opprettholdes ganske så klart, her fra Andrea Kroksnes' etterord i den norske utgivelsen av Bourriauds bok:

\begin{abstract}
På et mer populistisk eller polemisk nivå er kunstverkene [...] blitt sammenliknet med underholdningskulturens begivenhetskultur. Den levde kroppslige erfaringen i tilskuerdeltakelse gjør det lett å trekke en parallell til temaparker og underholdningsindustri. I en tid da museer og kulturinstitusjoner faktisk konkurrerer med underholdningsindustrien om publikumstall, sponsorstøtte og mediedekning er dette en sammenblanding som er ikke helt uproblematisk. I prosessen der skillet mellom kunsten og nabo-områdene blir stadig mer porøs, vil også kunstverdenens relative autonomi kunne gå tapt (Bourriaud 2007:184).
\end{abstract}

Populærkulturens relasjonelle estetikk ligger og trykker under overflaten, noe som her gjøres til et problem. Kroksnes fortsetter med å spørre: “ [...] hvordan kan man antyde at relasjonell estetikk virkelig er identisk med underholdningskulturen [...]?” (s. 186). Og ikke nok med det: “[...] selv om relasjonell estetikk ikke står frem som en av de mest politiske krefter i samtidens kultur, er det ikke dermed sagt at dens mer bekreftende og tvetydige holdning til underholdningskulturen gjør denne kunsten mislykket” (Bourriaud 2007:188). Her innrømmes det at den relasjonelle kunsten er relatert i stor grad til underholdningskulturen gjennom bekreftelse og tvetydighet, men at den allikevel, ja på tross av nettopp dette, ikke er mislykket. Her er det åpenbart noe på spill! Det er klart at store deler av ulike fagmiljø og tradisjoner er kritiske til å se paralleller, likheter og sammenfallende strategier mellom det vi (ennå) kaller "kunst”, og det vi kaller “pop". Kanskje det er på tide å se nærmere på populærkulturelle fenomener $\mathrm{i}$ et kunstnerisk lys, slik vi har sett blant annet hos den amerikanske estetikeren og filosofen Richard Shusterman: 
For rap, I believe, is a postmodern popular art which challenges some of our deeply entrenched aesthetic conventions, conventions which are common not only to modernism as an artistic style and ideology but to the philosophical doctrine of modernity and its sharp differentiation of cultural spheres (Shusterman 2000:201).

Problemet her er ikke nytt og vi har sett det før, spesielt knyttet til akademiske arbeider på jazzmusikk. Günther Schuller (1989) og André Hodeir (1956) benytter seg av liknende strategier når deres analyser av jazzkomposisjoner og utøvere benytter seg av begrep som "mesterkomponist" og "mesterverk". Vi mener dog her at Shustermans motiv er viktig. Dette er å ta rapmusikk på alvor som en kompleks, krevende og avansert form for musikk. Men hans strategi er mer tvilsom. Her ser vi en klar opprettholdelse av dikotomien høy/lav, der rappen skal "opphøyes" til "kunst” på linje med andre verdige musikalske kunsttradisjoner. I tillegg verdsettes rapmusikken på en bakgrunn av dens objekter, dette vil si innspilte låter tatt ut av sin sammenheng (riktignok sett i en kulturell sammenheng, men det er noe annet). Et nødvendig fokus på rapmusikk som kulturell og sosial praksis, og ikke som kunst, blir blendet av et lysende skinn fra kunstdiskursen og estetikkens glorete lamper.

Samtidskunsten, ifølge Bourriaud, skal og bør gi nye "rom", med nye, annerledes rytmer og modaliteter enn det "normale" dagligdagse som er preget av mekaniske rytmer. Dermed er kunst en møtetilstand mellom mennesker der spillmetaforen er viktig - kunst er et mellommenneskelig spill. Samtidskunsten modellerer dermed aktivt måter å vcere på. Den har ingenting med kun å "speile" eller å "referere til" å gjøre, noe som minner oss om en fortolkning av kunst som et passivt fenomen i samfunnet. Dermed kan det kanskje vise seg at deler av kunstfeltet er i ferd med å komme frem til de "estetiske" praktiske løsningene på mellommenneskelige tilværelser som populærmusikken i lang tid tross alt har hatt som sitt sentrale bærende element.

\section{Referanser}

Appadurai, A. (2006). Fear of small numbers: An essay on the geography of anger.

Durham and London: Duke University Press.

Bourdieu, P. (1984). Distinction: A social critique of the judgement of taste.

Cambridge: Harvard University Press.

Bourriaud, N. (2007 [1998]). Relasjonell estetikk. Oslo: Pax Forlag A/S. Oversatt av Boel Christensen-Scheel.

Dewey, J. (1934). Art as experience. London: Penguin Books. 
Frith, S. (1996). Music and identity. I Questions of cultural identity.

Hall, S. \& du Gay, P. (red.). London: Sage Publications.

Hodeir, A. (1956). Jazz: It's evolution and essence. New York: Grove Press.

Jørgensen, S.H. (2004). På sporet av improvisasjonens potensiale, Dr.art.avhandling. Trondheim: NTNU.

Latour, B. (2005). Reassembling the social: An introduction to actornetwork-theory. Oxford: Oxford University Press.

Schuller, G. (1989). The swing era: The development of jazz, 1930-1945. New York: Oxford University Press.

Shusterman, R. (2000). Pragmatist aesthetics; living beauty, rethinking art. (2nd ed.). Maryland: Rowman \& Littlefield Publishers Inc.,

Small, C. (1987). Music of the common tounge; survival and celebration in African American music; Hanover: Wesleyan University Press.

Small, C. (1998). Musicking: the meanings of performing and listening. Middletown: Wesleyan University Press.

Stokes, M. (red.) (1994). Ethnicity, identity and music. The musical construction of place. Oxford and New York: Berg Publishers.

Turner, V.W. (1969). The ritual process: Structure and anti-structure. Hawthorne, New York: Aldine de Gruyter. 